\title{
Clinical Characteristics and Spermatogenesis in Patients with Congenital Hypogonadotropic Hypogonadism Caused by FGFR1 Mutations
}

\author{
Shuying Li ${ }^{1},{ }^{1}$ Yaling Zhao ${ }^{1},{ }^{1}$ Min Nie, ${ }^{1}$ Wanlu Ma, ${ }^{1}$ Xi Wang, ${ }^{1}$ Wen Ji, ${ }^{1}$ Yufan Yang, \\ Ming Hao, ${ }^{1,2}$ Bingqing Yu, ${ }^{1}$ Yinjie Gao, ${ }^{1}$ Jiangfeng Mao $\mathbb{D}^{1},{ }^{1}$ and Xueyan $W u\left(\mathbb{D}{ }^{1}\right.$ \\ ${ }^{1}$ Department of Endocrinology, Peking Union Medical College Hospital, Peking Union Medical College, \\ Chinese Academy of Medical Sciences, Beijing 100730, China \\ ${ }^{2}$ Department of Endocrinology, The First Affiliated Hospital of Harbin Medical University, Harbin 150001, China
}

Correspondence should be addressed to Jiangfeng Mao; maojiangfeng88@vip.sina.com and Xueyan Wu; wsheyan@vip.sina.com

Received 6 August 2020; Revised 30 October 2020; Accepted 5 November 2020; Published 28 November 2020

Academic Editor: Rosaria Meccariello

Copyright (c) 2020 Shuying Li et al. This is an open access article distributed under the Creative Commons Attribution License, which permits unrestricted use, distribution, and reproduction in any medium, provided the original work is properly cited.

Objective. The aim of this study was to investigate the clinical characteristics of patients diagnosed with congenital hypogonadotropic hypogonadism (CHH) caused by FGFR1 (fibroblast growth factor receptor 1) gene mutations and to evaluate the effect of gonadotropin or pulsatile gonadotropin-releasing hormone (GnRH) therapy on spermatogenesis. Methods. A retrospective study was conducted on $\mathrm{CHH}$ patients admitted to Peking Union Medical College Hospital from January 2012 to March 2020. Clinical features and laboratory results were recorded. Testicular volume and sperm count responding to gonadotropin and pulsatile GnRH therapy were compared between the FGFR1 mutation group and the mutation-negative group. Results. (1) FGFR1 mutation group included 14 patients who received sperm-induction therapy, and the mutation-negative group enrolled $25 \mathrm{CHH}$ patients. (2) The incidence of cryptorchidism was $50.0 \%(7 / 14)$ and $12.0 \%(3 / 25)$ in the FGFR1 group and the mutation-negative group, respectively $(p=0.019)$. The baseline testicular volume of the FGFR1 mutation group was smaller than that of the mutation-negative group, $1.6(0.5-2.0) \mathrm{mL}$ vs. $2(1.75-4) \mathrm{mL}(p=0.033)$. The baseline luteinizing hormone (LH), Folliclestimulating hormone (FSH), and testosterone levels were similar between the two groups. (3) Using the Kaplan-Meier and logrank tests for the analysis of spermatogenesis, it was found that there was no significant difference in the first sperm appearance between the FGFR1 mutation group and the mutation-negative group $\left(\chi^{2}=1.974, p=0.160\right)$. The median time of spermatogenesis in the FGFR1 mutation group was longer than that in the mutation-negative group, 16 months vs. 10 months, respectively. The cumulative spermatogenesis success rate at 12 months in the FGFR1 mutation group (35.71\%) was lower than that in the mutation-negative group $(68.75 \%)(p=0.047)$. The sperm concentration in the mutation-negative group was more easily achieved for different thresholds compared with that in the FGFR1 mutation group, but no significant difference was observed $(p>0.05)$ between the two groups. The last follow-up examination showed that the testicular volume was 7.00 $(4.75-12.00) \mathrm{mL}$ and $10.56 \pm 4.82 \mathrm{~mL}(p=0.098)$, the ejaculate volume of sperm was $2.20(1.40-2.26) \mathrm{mL}$ and $3.06 \pm 1.42 \mathrm{~mL}(p=0.175)$, and the sperm concentration was $7.19(1.00-9.91)$ million/mL and $18.80(4.58-53.62)$ million $/ \mathrm{mL}(p=0.038)$ in the FGFR1 mutation and mutation-negative groups, respectively, while the sperm motility ( $\mathrm{A} \%, \mathrm{~A}+\mathrm{B} \%$, and $\mathrm{A}+\mathrm{B}+\mathrm{C} \%$ ) was similar for the two groups $(p=0.839,0.909$, and 0.759 , respectively). The testosterone level during treatment was $366.02 \pm 167.03 \mathrm{ng} / \mathrm{dL}$ and $362.27 \pm 212.86 \mathrm{ng} / \mathrm{dL}$ in the FGFR1 mutation and mutation-negative groups, respectively $(p=0.956)$. Conclusion. Patients with FGFR1 mutations have a higher prevalence of cryptorchidism and smaller testicular volume. Although patients with FGFR1 mutations have a similar rate of success for spermatogenesis compared to that of the mutation-negative patients, a longer treatment period was required and a lower sperm concentration was achieved. 


\section{Introduction}

Male congenital hypogonadotropic hypogonadism $(\mathrm{CHH})$ is a secondary testicular hypofunction caused by gonadotropin-releasing hormone (GnRH) secretion or action defects. The incidence in males is approximately $1 / 5,000-8,000$ [1]. Patients are characterized by delayed pubertal development and infertility. The disease was clinically classified into Kallmann syndrome (with anosmia) and normosmic $\mathrm{CHH}$. Patients typically require lifetime testosterone replacement therapy. When fertility is required, pulsatile GnRH or gonadotropin (HCG/HMG) therapy allows most patients to produce sperm.

In recent years, a number of gene mutations have been found to cause $\mathrm{CHH}$, including ANOS1 (anosmin 1), FGFR1, FGF8 (fibroblast growth factor 8), PROKR2 (prokineticin receptor 2), PROK2 (prokineticin 2), CHD7 (chromodomain helicase DNA binding protein 7), WDR11 (WD repeat domain 11), TACR3 (tachykinin receptor 3), TAC3 (tachykinin 3), KISS1R (KISS1 receptor), NSMF (NMDA receptor synaptonuclear signaling and neuronal migration factor), HS6ST1 (heparan sulfate 6-O-sulfotransferase 1), SOX2 (SRY-box transcription factor 2), and SEMA3A (semaphorin $3 A$ ) [2]. Pathogenic gene mutations were identified in approximately half of the $\mathrm{CHH}$ patients, of which $10-20 \%$ are due to an inactivating FGFR1 mutation [3]. Studies have shown variable degrees of function in the reproductive axis and other phenotypes are associated with different mutated genes [4].

Mutation of FGFR1 is an important cause of $\mathrm{CHH}$ and previous studies have suggested that FGFR1 mutations may cause more severe damage to the hypothalamic-pituitarytestis axis [5]. The protein encoded by FGFR1 expressed on the cellular membranes of various cell types is a member of the fibroblast growth factor receptor (FGFR) family [6, 7]. There are three IgG-like molecules in the extracellular domain, which is the key region of ligand binding. FGFR is divided into four categories, namely, FGFR1, FGFR2, FGFR3, and FGFR4. Its ligand consists of several fibroblast growth factor (FGF) members, mainly FGF-2 and FGF-8. FGFs and the FGFR1 system play important roles in cell differentiation and proliferation, embryonic development, angiogenesis, and endocrine signaling [8]. When the ligand binds to the receptor, FGFR1 forms a homodimer, which can activate the phosphorylation of intracapsular aspartate and play a biological role through transforming growth factor- $\beta$ (TGF- $\beta$ ) and Adenosine $5^{\prime}$-monophosphate (AMP) activated protein kinase (AMPK) pathways. Overactivation of FGFs and the FGFR1 system can cause multiple tumorigeneses [9], whereas inactivation mutations can cause developmental disorders of the nervous system (including olfactory bulb axons), migration disorders of $\mathrm{GnRH}$ neurons, and dental and skeletal development disorders [10]. FGFR1 gene mutations are expressed in a variety of cells throughout the body and are widely involved in the proliferation and differentiation of various cell types [11].

Currently, there is insufficient research conducted on sperm-inducing therapy in patients with FGFR1 mutations. This study aimed to evaluate the effects of spermatogenesis in patients with FGFR1 mutations by comparing the disparity between the FGFR1 group and the mutation-negative group.

\section{Patients and Methods}

2.1. Patients. $\mathrm{CHH}$ patients who were admitted to the Peking Union Medical College Hospital from January 2012 to March 2020 were recruited, and the clinical data were retrospectively collected.

Inclusion criteria: (1) $\mathrm{CHH}$ males were diagnosed if the patient fulfilled all the following conditions: no pubertal development after 18 years old, blood testosterone $\leq 100 \mathrm{ng} /$ $\mathrm{dL}$ with a low or inappropriately normal level of serum gonadotropins, normal secretion of other anterior pituitary hormones, and normal magnetic resonance (MR) imaging in the seller region; (2) sperm-inducing therapy was administered to patients; (3) FGFR1 mutation group (FM group): FGFR1 gene mutations were identified by high-throughput next-generation sequencing, then verified by Sanger sequencing, and the pathogenicity was determined by the American College of Medical Genetics and Genomics (ACMG) guidelines [12]; (4) the control group (mutationnegative group, $\mathrm{MN}$ group): $\mathrm{CHH}$ patients who had no gene mutation detected after high-throughput next-generation sequencing.

Exclusion criteria: (1) patients with any other gene mutations that were pathogenic or likely pathogenic genes of $\mathrm{CHH}$ by the ACMG guidelines; (2) patients with uncompleted medical records; (3) patients who did not receive sperm-inducing treatment. Written informed consent was obtained from all patients. The patient inclusive procedure is shown in Figure 1.

\subsection{Therapeutic Regimes and Patient Follow-Up.} Pathogenic genes were screened by a next-generation sequencing panel, which included (but not limited to) FGF8 and its receptor FGFR1, GNRH1 and its receptor GNRHR, $P R O K 2$ and its receptor $P R O K R 2, T A C 3$ and its receptor TACR3, LEP and its receptor LEPR, and CHD7, ANOS1, KISS1R, NSMF, WDR11, LHB, FSHB, and PCSK1 [1, 13-16]. The $\mathrm{CHH}$-related genes included in the panel are shown in Supplementary Table 1. High-throughput next-generation sequencing was used to identify patients with FGFR1 mutations. Sanger sequencing was performed on patients and their parents to verify and track FGFR1 mutations (The specific process and method of the next-generation sequencing are shown in Supplementary Material 2).

Clinical data collected from FGFR1 gene mutation and $\mathrm{MN}$ patients undergoing spermatogenesis treatment included the following information: age; body mass index (BMI); clinical characteristics outside the gonadal axis; age for starting spermatogenesis treatment; a history of cryptorchidism; testis volume before and after spermatogenesis treatment; a history of testosterone replacement therapy before spermatogenesis treatment; the ejaculate volume and concentration in the follow-up duration; sperm motility, which was classified as fast progressive sperm (A), slow 
$330 \mathrm{CHH}$ patients admitted from January 2012 to March 2020 were sequenced

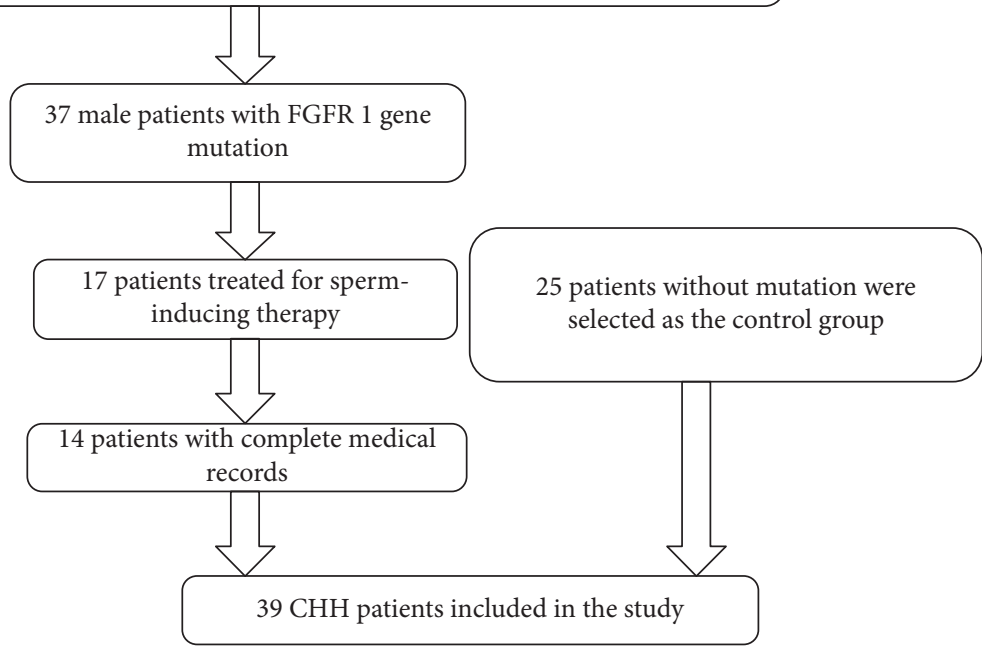

Figure 1: Flow chart of patient inclusion criteria.

progressive sperm (B), and nonprogressive sperm (C); $\mathrm{LH}$, $\mathrm{FSH}$, and testosterone levels during the treatment. For $\mathrm{LH}$, $\mathrm{FSH}$, and testosterone, the average values of the last two visits were taken for data analysis. The ejaculate volume, sperm concentration, and sperm motility at the last followup were analyzed.

Testicular volume was measured by two gonadal clinical specialists. During the follow-up examination, testis volume was measured by direct comparison with the orchidometer. If there were bilateral testicles, the average value was taken. If the testis was unilateral (cryptorchidism was on the other side), the descended testis volume was taken for statistical analysis. The average testicular size of the last two visits was defined as the testicular size after therapy for data analysis. The first sperm was detected under the microscope, and semen was centrifugated if necessary.

Patients discontinued androgen therapy (if used) for at least 3 months before starting gonadotropins therapy. Human chorionic gonadotrophin/human menopausal gonadotropin (HCG/HMG) treatment included intramuscular injection of 2000-3000 IU of HCG and 75 IU of HMG twice a week. The HCG dose was adjusted according to the testosterone level, which was maintained at $200-400 \mathrm{ng} / \mathrm{dL}$. Pulsatile GnRH treatment included a subcutaneous injection of pulsatile gonadorelin, starting at a dosage of $10 \mu \mathrm{g} / 90 \mathrm{~min}$. The dosage was adjusted according to the levels of $\mathrm{LH}$ and testosterone, and the level of testosterone was maintained at 200-400 ng/dL. Follow-up was conducted at an interval of 3-6 months. The seminal test, sex hormone, and testis volume were measured during each visit.

2.3. Statistical Analysis. SPSS version 23.0 was used for analyzing the difference between $\mathrm{CHH}$ patients with and without FGFR1 gene mutations who received spermatogenic therapy. Normally distributed data are expressed as the mean $\pm S D$, and nonnormally distributed data are expressed as the median (quartiles). The nonpaired $t$-test was used to compare data between two groups, such as the plasma testosterone and testicular volumes, if the data were normally distributed. If the two groups of data were not normally distributed, nonparametric tests were used to test the significance of the difference between the two groups. The Kaplan-Meier and log-rank tests were used for the analysis of spermatogenesis. The chi-square test was used to compare the rates between groups. When $p<0.05$, it was considered statistically significant.

\section{Results}

3.1. Baseline Characteristic Comparison between the FGFR1 Group and the Mutation-Negative Group. From January 2012 to March 2020, $330 \mathrm{CHH}$ patients underwent panel gene sequencing. Among them, 37 patients had FGFR1 gene mutation. 17 among the 37 patients received sperm-inducing treatment. Among the 17 patients, 14 had complete medical records. A total of 14 patients with FGFR1 gene mutations were included. 25 patients without mutations who matched the FGFR1 group with a complete medical record and matched the age of spermatogenesis, preuse, and use time of testosterone were selected as the control group (Figure 1). The mutation types of FGFR1 were heterogeneous, including 11 missense mutations, 2 frame shift mutations, and 1 deletion mutation. Four patients with FGFR1 gene mutations were sequenced for the source of the mutations, and all were de novo mutations (Table 1).

In the FM group, 11 patients had previous testosterone therapy for 1 (1-2) years, while in the MN group, 12 patients had been treated with testosterone for 1 (0.5-4) years. The age for starting spermatogenic treatment was $20.00(18.75-24.75)$ years and $24.12 \pm 5.75$ years $(p=0.297)$, the testicular volume was $1.6(0.5-2.0) \mathrm{mL}$ and $2.0(1.75-4) \mathrm{mL}(p=0.033)$, the LH level was 0.20 $(0.10-0.70)$ IU/L and $0.35(0.20-0.72) \mathrm{IU} / \mathrm{L}$, and the 
TABLE 1: FGFR1 mutation type, specific site information, and pathogenicity.

\begin{tabular}{|c|c|c|c|}
\hline Mutation types & Mutation site & Inherited & Pathogenicity \\
\hline \multirow{11}{*}{ Missense mutation } & p.V184M (c.550G > A) & Unknown & Likely pathogenic \\
\hline & p.R477T (c.1430G > C) & Unknown & Uncertain \\
\hline & p.A342V (c.1025C > T) & Unknown & Uncertain \\
\hline & p.F186I $($ c.556T > A $)$ & Unknown & Uncertain \\
\hline & p.H452P $($ c.1355A > C) & Unknown & Uncertain \\
\hline & p.V184M (c.550G > A) & Unknown & Likely pathogenic \\
\hline & p.T340M $(c .1019 \mathrm{C}>\mathrm{T})$ & Unknown & Likely pathogenic \\
\hline & p.G260R $($ c.778G > C) & De novo & Likely pathogenic \\
\hline & p.R254W (c.760C > T) & De novo & Likely pathogenic \\
\hline & p.R424H $(\mathrm{c} .1271 \mathrm{G}>\mathrm{A})$ & Unknown & Uncertain \\
\hline & p.R165Q (c.494G > A) & Unknown & Uncertain \\
\hline \multirow{2}{*}{ Frame shift mutation } & p.L188Hfs $* 5$ (c.562_563insAC) & De novo & Pathogenic \\
\hline & p.Y280Lfs $* 2$ (c.838dupT) & De novo & Pathogenic \\
\hline Deletion mutation & p.733_733del (c.2197_2199delATG) & Unknown & Uncertain \\
\hline
\end{tabular}

baseline testosterone was $24.1(18.58-37.25) \mathrm{ng} / \mathrm{dL}$ and $32.70(20.65-46.5) \mathrm{ng} / \mathrm{dL}$ (measured after stopping testosterone replacement therapy for at least 3 months) in the FM group and the MN group, respectively (Table 2).

\subsection{FGFR1 Mutation Group Had Higher Incidence of} Cryptorchidism. There were seven cases of cryptorchidism in the FGFR1 group (50.0\%): three were unilateral and four were bilateral. There were three cases of cryptorchidism in the MN group (12.0\%): one was unilateral and two were bilateral (Table 2 ).

\subsection{Treatment Time for the First Appearance of Spermatozoa.} In the MN group, one patient had received sperm-inducing treatment, but there was no information from the first follow-up. Therefore, this patient was excluded from the spermatogenesis analysis. The mean follow-up period was similar between the two groups: $26.36 \pm 8.54$ months in the FM group and $22.54 \pm 8.74$ months in the $\mathrm{MN}$ group $(p=0.199)$ (Table 3).

The median time for the first sperm appearance in semen of the FM group was longer than that of the MN group (16 vs. 10 months, $95 \%$ CI: 7.62 to 24.39 months and 5.45 to 14.55 months) after induced spermatogenesis therapy. Analysis of spermatogenesis using the Kaplan-Meier and log-rank test showed that there was no difference in the overall spermatogenesis rate between the two groups $\left(\chi^{2}=1.974, p=0.160\right)$ (Figure 2(a)). The successful rate of spermatogenesis at 12 and 24 months of treatment was $35.71 \%$ and $75.89 \%$ in the FM group, and $68.75 \%$ and $82.14 \%$ in the MN group, with $p$ values of 0.047 and 0.160 between the two groups, respectively (Table 3 and Figure 2(a)). At the final visit, the testis volume was $7.00(4.75-12.00)$ and $10.56 \pm 4.82 \mathrm{~mL}(p=0.098)$, and the testosterone level was $366.02 \pm 167.03$ and $362.27 \pm 212.86 \quad(n=24) \quad n g / d L$ $(p=0.956)$ in the $\mathrm{FM}$ and $\mathrm{MN}$ groups, respectively (Table 3).

In the FM group, four patients were treated with pulsatile $\mathrm{GnRH}$, and the final dosage of $\mathrm{GnRH}$ was gradually adjusted to $9.5 \pm 3.42(6-14) \mu \mathrm{g} / 90 \mathrm{~min}$, the LH level increased to $8.46 \pm 3.31 \mathrm{IU} / \mathrm{L}$, the $\mathrm{FSH}$ level increased to $9.77 \pm 6.20 \mathrm{IU} / \mathrm{L}$, and the testosterone level increased to $286.95 \pm 130.11 \mathrm{ng} / \mathrm{dL}$. Among these patients, one switched from 12-month gonadotropin therapy to pulsatile $\mathrm{GnRH}$ therapy. Ten patients in the FM group received gonadotropin therapy. The final adjusted dosage was $2600 \pm 516.40$ (2000-3000) IU for HCG and 75 IU for HMG, twice weekly. The testosterone level increased to $397.65 \pm 189.78 \mathrm{ng} / \mathrm{dL}$ (Table 3).

In the MN group, 13 patients received pulsatile $\mathrm{GnRH}$ treatment. The $\mathrm{LH}$ level increased to $7.59 \pm 4.07 \mathrm{IU} / \mathrm{L}$, the FSH level increased to $9.75 \pm 4.01 \mathrm{IU} / \mathrm{L}$, the testosterone level increased to $304.54 \pm 167.03 \mathrm{ng} / \mathrm{dL}$, and the final dosage of $\mathrm{GnRH}$ was gradually adjusted to $10.08 \pm 4.11(4-20) \mu \mathrm{g} /$ $90 \mathrm{~min}$. The other 11 patients received gonadotropin treatment and the testosterone level increased to $431.76 \pm 247.42 \mathrm{ng} / \mathrm{dL}$. The final adjusted dosage was $2500 \pm 527.05$ (2000-3000) IU for HCG and 75 IU for HMG, twice weekly (Table 3 ).

3.4. Semen Parameters after Sperm-Inducing Treatment. Analysis of attaining different sperm concentration thresholds $(0,5,10,15$, and 20 million/mL) using Kaplan-Meier and log-rank tests showed that there was no significant difference in overall spermatogenesis rate between the FM and MN groups (Table 4 and Figure 2). The median time for sperm concentration to achieve 5 million/mL was 24 and 18.5 months in the FM and MN groups, respectively. The median time for sperm concertation to achieve $10 \mathrm{million} / \mathrm{mL}$ in the $\mathrm{MN}$ group was 20 months. However, other median times for sperm concentration to achieve different thresholds in the two groups cannot be obtained due to the small size of samples. During the last visit, the ejaculate volume in the FM and MN groups was measured to be $2.20(1.40-2.26) \mathrm{mL}$ and $3.06 \pm 1.42 \mathrm{~mL}$ $(p=0.175)$, and the sperm concentration was 7.19 (1.00-9.91) million/mL and 18.80 (4.58-53.62) million/mL, respectively $(p=0.038$ ) (Figure 3 ), while the sperm motility (A\%, A + B\%, and A + B + C\%) was similar between the two groups ( $p=0.839,0.909$, and 0.759 , respectively). 
TABLE 2: Comparison of clinical characteristics between the FGFR1 gene group and the mutation-negative group at baseline.

\begin{tabular}{|c|c|c|c|}
\hline Groups & $\begin{array}{l}\text { FGFR1 mutation } \\
\quad(n=14)\end{array}$ & Mutation-negative $(n=25)$ & $p$ \\
\hline Kallmann/nCHH (n/n) & $8 / 6$ & $20 / 5$ & 0.156 \\
\hline Gonadotropin/GnRH pulsatile $(\mathrm{n} / n)$ & $10 / 4$ & $12 / 13$ & 0.193 \\
\hline $\begin{array}{l}\text { Number of testosterone users before } \\
\text { sperm promoting therapy }(n, \%)\end{array}$ & $11,78.57 \%$ & $12,480.00 \%$ & 0.093 \\
\hline $\begin{array}{l}\text { Previous testosterone treatment course } \\
\text { (years) }\end{array}$ & $1(1-2)(n=11)$ & $1(0.5-4)(n=12)$ & 0.441 \\
\hline $\begin{array}{l}\text { Cryptorchidism or history of } \\
\text { cryptorchidism }(n, \%)\end{array}$ & $\begin{array}{c}7,50.0 \% \\
\text { (Unilateral/ } \\
\text { Bilateral }=3 / 4)\end{array}$ & $3,12.0 \% *($ Unilateral $/$ Bilateral $=1 / 2)$ & 0.019 \\
\hline $\begin{array}{l}\text { Age of start for spermatogenic treatment } \\
\text { (years) }\end{array}$ & $20.00(18.75-24.75)$ & $24.12 \pm 5.75$ & 0.297 \\
\hline Baseline testicular size $(\mathrm{mL})$ & $1.6(0.5-2.0)$ & $2.0(1.75-4) * *$ & 0.033 \\
\hline Baseline LH (IU/L) & $0.20(0.10-0.70)$ & $0.35(0.20-0.72)$ & 0.318 \\
\hline Baseline FSH (IU/L) & $1.01 \pm 0.85$ & $0.60(0.22-1.58)$ & 0.714 \\
\hline Baseline testosterone (ng/dL) & $24.1(18.58-37.25)$ & $32.70(20.65-46.5)$ & 0.198 \\
\hline $\begin{array}{l}\text { LH } 60 \text { min after triptorelin stimulating test } \\
\text { (IU/L) }\end{array}$ & $2.3(1.16-5.68)$ & $1.75(0.77-5.78)$ & 0.529 \\
\hline
\end{tabular}

Nonreproductive phenotype

Obesity $(n=2)$

Obesity $(n=3)$; diabetes $(n=1)$; solitary kidney $(n=1)$; strabismus $(n=1)$; unilateral ptosis $(n=1)$; multiple facial nevi $(n=1)$;

TABLE 3: Sperm production during therapy.

\begin{tabular}{|c|c|c|c|}
\hline Groups & FGFR1 mutation $(n=14)$ & Mutation-negative $(n=24)$ & $p$ \\
\hline Mean follow-up time (months) & $26.36 \pm 8.54$ & $22.54 \pm 8.74$ & 0.199 \\
\hline Cumulative success rate of achieving first $s$ & $35.71 \%$ & $68.75 \%$ & 0.047 \\
\hline Cumulative success rate of achieving first sperm appearance in 2 years & $75.89 \%$ & $82.14 \%$ & 0.160 \\
\hline Testicular volume $(\mathrm{mL})$ & $7.00(4.75-12.00)$ & $10.56 \pm 4.82(n$ & 0.098 \\
\hline one (ng/dL) & $366.02 \pm 16$ & $362.27 \pm 2$ & 0.956 \\
\hline satile $\mathrm{GnF}$ & $286.95 \pm 13$ & $54 \pm 1$ & 0.857 \\
\hline Testosterone in gonadotropin therapy (ng/dL) & $397.65 \pm 189.78(n=10)$ & $431.76 \pm 247.42(n=11)$ & 0.729 \\
\hline FSH in GnRH pulsatile thera & $9.77 \pm 6.20(n=4)$ & $9.75 \pm 4.01(n=13)$ & 0.993 \\
\hline LH in GnRH pulsatile therapy (IU/L) & $8.46 \pm 3.31(n=4)$ & $7.59 \pm 4.07(n=13)$ & 0.737 \\
\hline
\end{tabular}

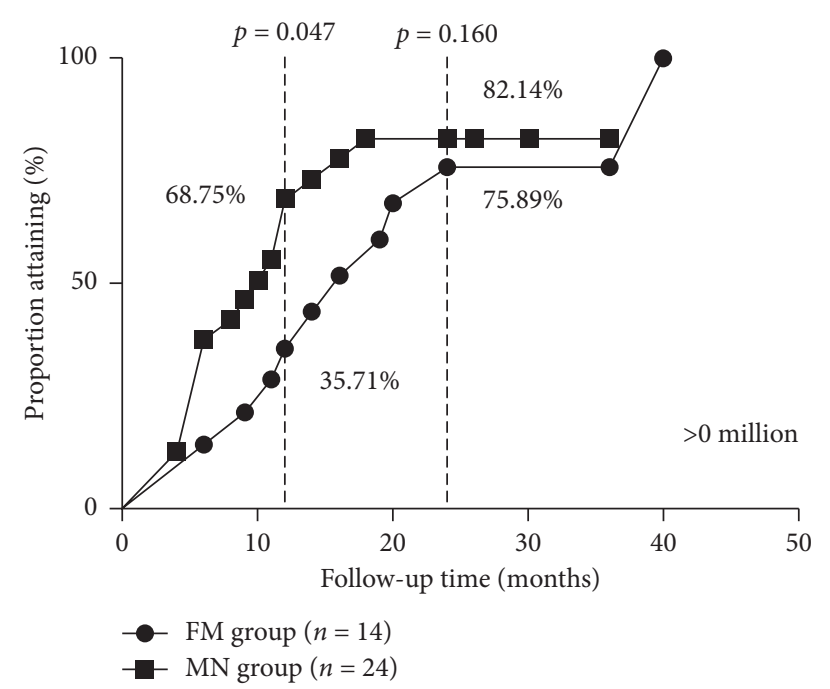

(a)

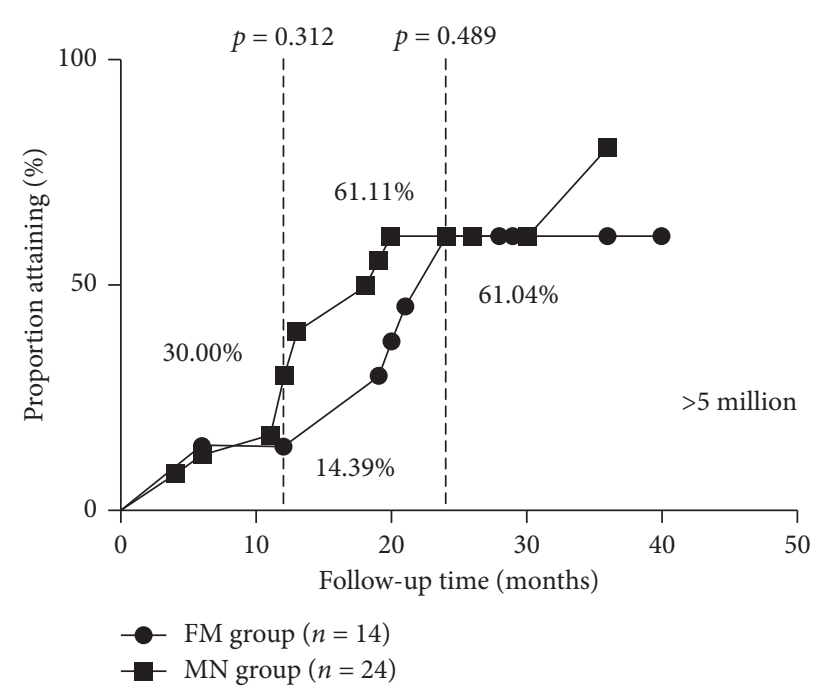

(b)

Figure 2: Continued. 


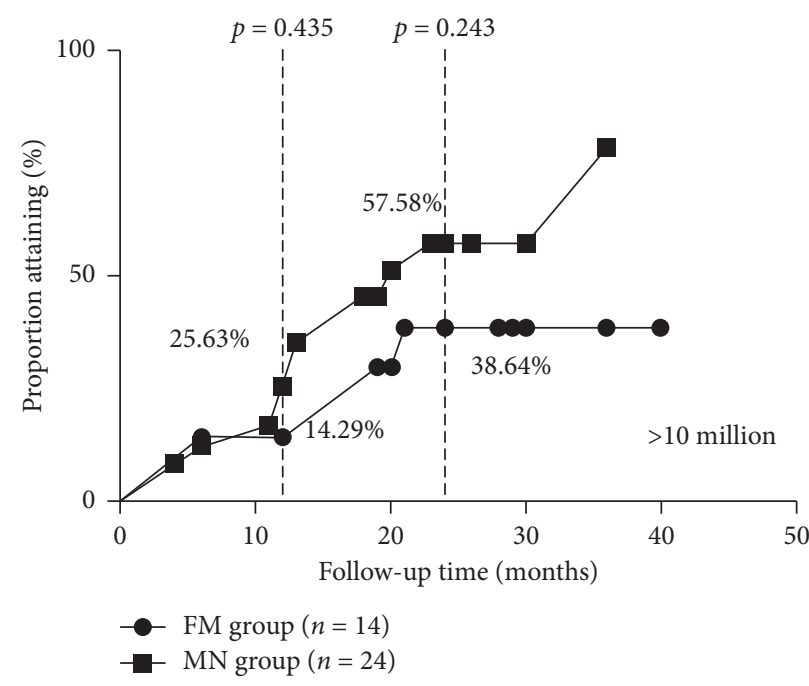

(c)

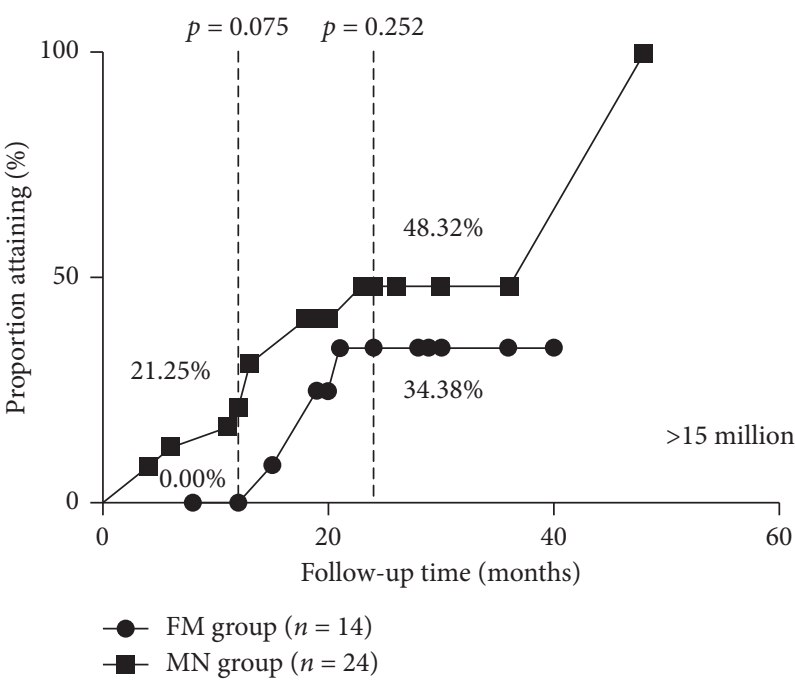

(d)

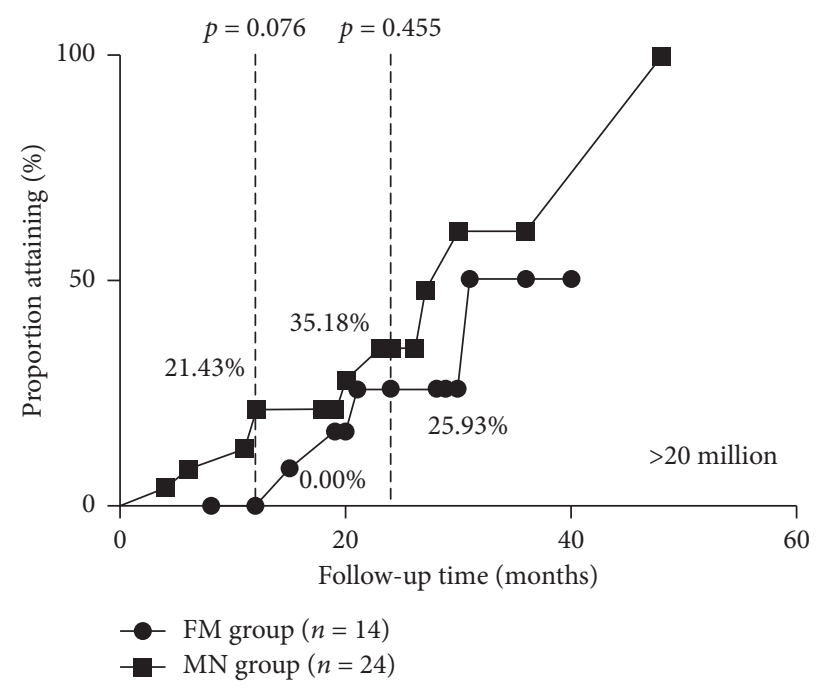

(e)

Figure 2: (a) Kaplan-Meier curve for achieving sperm concentration more than 0 million/ml (first sperm appearance) in FM and MN groups. (b) Kaplan-Meier curve for achieving sperm concentration more than 5 million/ml (first sperm appearance) in FM and MN groups. (c) Kaplan-Meier curve for achieving sperm concentration more than $10 \mathrm{million} / \mathrm{ml}$ (first sperm appearance) in FM and MN groups. (d) Kaplan-Meier curve for achieving sperm concentration more than $15 \mathrm{million} / \mathrm{ml}$ (first sperm appearance) in FM and MN groups. (e) Kaplan-Meier curve for achieving sperm concentration more than $20 \mathrm{million} / \mathrm{ml}$ (first sperm appearance) in FM and MN groups.

3.5. Patients Who Failed to Produce Sperm after Two Years of Treatment. Six patients failed to produce sperm after two years of treatment, two were in the FM group and four were in the $\mathrm{MN}$ group. Among these patients, three had a history of cryptorchidism. During the follow-up examination, the testosterone mean level was as low as $79.65 \mathrm{ng} / \mathrm{dL}(32.8-148 \mathrm{ng} /$ $\mathrm{dL}$ ), and four patients had testis size smaller than or equal to $5 \mathrm{~mL}$ (Table 5).

\section{Discussion}

Our research focused on the clinical characteristics and spermatogenesis of patients with FGFR1 gene mutations who underwent sperm-inducing treatment. We found that the FM patients had a higher incidence of cryptorchidism (50.0\% vs. $12.0 \%, p=0.019)$ and smaller testis size ( 1.6 vs. $2.0 \mathrm{~mL}, p=0.033)$ compared to patients without positive gene mutations. After a year of sperm promoting therapy, the MN group had a higher rate of achieving successful spermatogenesis than the FM group (35.71\% vs. $68.75 \%, p=0.047)$. After two years of therapy, $75.9 \%$ of the patients in the FM group achieved successful spermatogenesis, similar to that of patients without gene mutations $(82.14 \%)$. The median time needed for first sperm achievement in the FM gene group was longer compared to that of the MN group (16 months vs. 10 months). At the last follow-up, the sperm concentration in the FM group was lower than that in 
TABLE 4: Semen parameters after sperm-inducing treatment.

\begin{tabular}{|c|c|c|c|c|}
\hline Groups & & FGFR1 mutation $(n=14)$ & Mutation-negative $(n=24)$ & $p$ \\
\hline \multirow{2}{*}{ Cumulative rate of sperm concentration $>5$ million } & 1 years & $14.39 \%$ & $30.00 \%$ & 0.312 \\
\hline & 2 years & $61.04 \%$ & $61.11 \%$ & 0.489 \\
\hline \multirow{2}{*}{ Cumulative rate of sperm concentration $>10$ million } & 1 years & $14.29 \%$ & $25.63 \%$ & 0.435 \\
\hline & 2 years & $38.64 \%$ & $57.58 \%$ & 0.243 \\
\hline \multirow{2}{*}{ Cumulative rate of sperm concentration $>15$ million } & 1 years & $0.00 \%$ & $21.25 \%$ & 0.075 \\
\hline & 2 years & $34.38 \%$ & $48.32 \%$ & 0.252 \\
\hline \multirow{2}{*}{ Cumulative rate of sperm concentration $>20$ million } & 1 years & $0.00 \%$ & $21.43 \%$ & 0.076 \\
\hline & 2 years & $25.93 \%$ & $35.18 \%$ & 0.455 \\
\hline Ejaculate volume $(\mathrm{mL})$ & & $2.20(1.40-2.26)(n=11)$ & $3.06 \pm 1.42(n=19)$ & 0.175 \\
\hline Sperm concentration (million/mL) & & $7.19(1.00-9.91)(n=11)$ & $18.80(4.58-53.62)(n=19)$ & 0.038 \\
\hline Fast progressive sperm (A) (\%) & & $18.00 \pm 19.92(n=11)$ & $16.77 \pm 13.00(n=19)$ & 0.839 \\
\hline Sperm progressive motility $(A+B)(\%)$ & & $33.83 \pm 26.31(n=11)$ & $34.88 \pm 22.71(n=19)$ & 0.909 \\
\hline Sperm total mobility $(A+B+C)(\%)$ & & $37.26 \pm 29.21(n=11)$ & $40.38 \pm 24.91(n=19)$ & 0.759 \\
\hline
\end{tabular}

Sperm concentration, sperm volume, fast progressive sperm, sperm progressive motility, and sperm total mobility were obtained from the last visit.

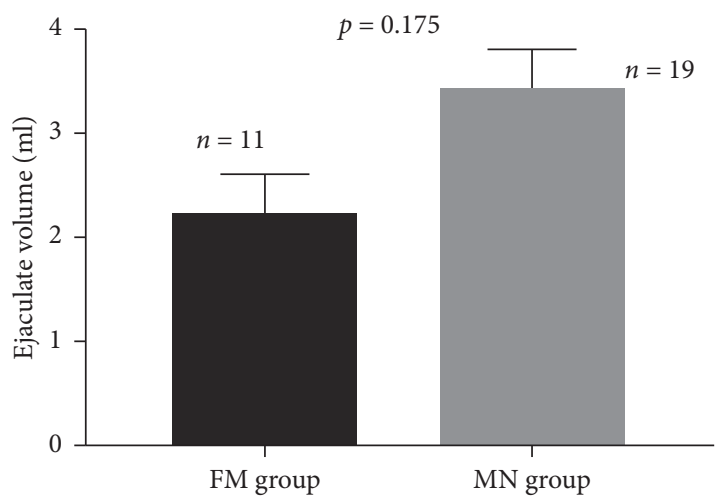

(a)

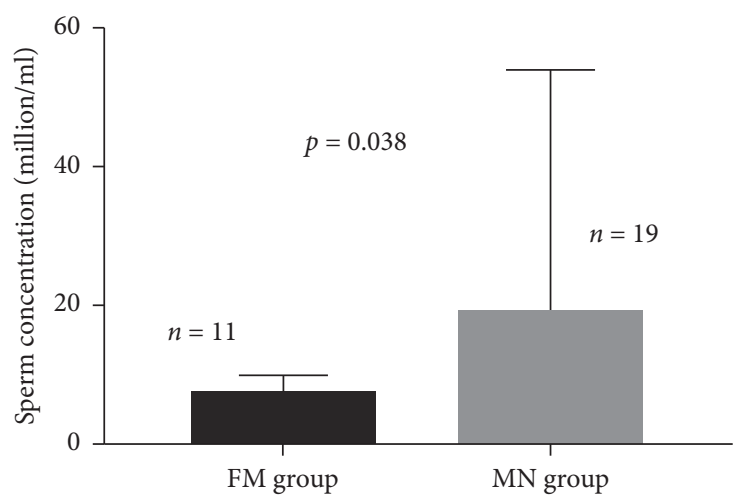

(b)

FigURE 3: Sperm parameters (ejaculate volume and concentration) after spermatogenesis treatment (the plot was described as median with interquartile range).

TABLE 5: Clinical manifestations and hormone levels in patients who had a failure of spermatogenesis.

\begin{tabular}{|c|c|c|c|c|c|c|c|}
\hline \multirow[t]{2}{*}{$\begin{array}{l}\text { Failure } \\
\text { cases }\end{array}$} & \multirow[t]{2}{*}{ Diagnosis } & \multirow{2}{*}{$\begin{array}{c}\begin{array}{c}\text { Gene mutation } \\
\text { type }\end{array} \\
\text { FGFR1 }\end{array}$} & \multicolumn{2}{|c|}{$\begin{array}{c}\text { General condition before spermatogenic } \\
\text { treatment }\end{array}$} & \multirow[t]{2}{*}{$\begin{array}{c}\text { Therapeutic } \\
\text { regime }\end{array}$} & \multicolumn{2}{|l|}{ Follow-up } \\
\hline & & & $\begin{array}{c}\text { Age for starting spermatogenic } \\
\text { therapy (year) }\end{array}$ & 20 & & $\begin{array}{l}\text { Follow-up duration } \\
\text { (months) }\end{array}$ & 36 \\
\hline & \multirow{7}{*}{$\mathrm{nCHH}$} & \multirow{7}{*}{$\begin{array}{c}\text { p.V184M (GTG- } \\
\text { >ATG) }\end{array}$} & BMI $\left(\mathrm{kg} / \mathrm{m}^{2}\right)$ & 32.8 & & Testicular size $(\mathrm{mL})$ & $5 / 5$ \\
\hline \multirow{6}{*}{ Patient 1} & & & $\begin{array}{l}\text { History of cryptorchidism or } \\
\text { cryptorchidism (yes/no) }\end{array}$ & Yes & \multirow{6}{*}{ GnRH pulsatile } & LH (IU/L) & 3.88 \\
\hline & & & Testicular size $(\mathrm{mL})$ & $2 / 2$ & & FSH (IU/L) & 3.8 \\
\hline & & & LH (IU/L) & 0.12 & & Testosterone (ng/dL) & 78.6 \\
\hline & & & FSH (IU/L) & 0.27 & & & \\
\hline & & & LH $60 \mathrm{~min}(\mathrm{IU} / \mathrm{L})$ & 1.05 & & & \\
\hline & & & Testosterone (ng/dL) & 31 & & & \\
\hline \multirow{8}{*}{ Patient 2} & \multirow{8}{*}{$\begin{array}{l}\text { Kallmann } \\
\text { syn }\end{array}$} & \multirow{8}{*}{$\begin{array}{c}\text { p.F186I (TTC- } \\
\text { >ATC) }\end{array}$} & $\begin{array}{c}\text { Age for starting spermatogenic } \\
\text { therapy (year) }\end{array}$ & 19 & \multirow{8}{*}{ Gonadotropin } & $\begin{array}{l}\text { Follow-up duration } \\
\text { (months) }\end{array}$ & 24 \\
\hline & & & $\operatorname{BMI}\left(\mathrm{kg} / \mathrm{m}^{2}\right)$ & 3.8 & & Testicular size $(\mathrm{mL})$ & $1 / 1$ \\
\hline & & & $\begin{array}{l}\text { History of cryptorchidism or } \\
\text { cryptorchidism (yes/no) }\end{array}$ & 19.4 & & LH (IU/L) & 0 \\
\hline & & & Testicular size $(\mathrm{mL})$ & Yes & & FSH (IU/L) & 0.15 \\
\hline & & & $\mathrm{LH}(\mathrm{IU} / \mathrm{L})$ & $0 / 1$ & & Testosterone (ng/dL) & 37.5 \\
\hline & & & FSH (IU/L) & 0.13 & & & \\
\hline & & & LH $60 \mathrm{~min}(\mathrm{IU} / \mathrm{L})$ & 0.6 & & & \\
\hline & & & Testosterone (ng/dL) & 1.01 & & & \\
\hline
\end{tabular}


TABLE 5: Continued.

\begin{tabular}{|c|c|c|c|c|c|c|c|}
\hline $\begin{array}{l}\text { Failure } \\
\text { cases }\end{array}$ & Diagnosis & $\begin{array}{c}\text { Gene mutation } \\
\text { type }\end{array}$ & $\begin{array}{c}\text { General condition before sperm } \\
\text { treatment }\end{array}$ & genic & $\begin{array}{c}\text { Therapeutic } \\
\text { regime }\end{array}$ & Follow-up & \\
\hline \multirow{8}{*}{ Patient 3} & \multirow{8}{*}{$\begin{array}{l}\text { Kallmann } \\
\text { syn }\end{array}$} & \multirow{8}{*}{$\begin{array}{l}\text { Mutation- } \\
\text { negative }\end{array}$} & $\begin{array}{c}\text { Age for starting spermatogenic } \\
\text { therapy (year) }\end{array}$ & 28 & \multirow{8}{*}{ GnRH pulsatile } & $\begin{array}{c}\text { Follow-up duration } \\
\text { (months) }\end{array}$ & 24 \\
\hline & & & BMI $\left(\mathrm{kg} / \mathrm{m}^{2}\right)$ & 37.4 & & Testicular size $(\mathrm{mL})$ & $3 / 3$ \\
\hline & & & $\begin{array}{l}\text { History of cryptorchidism or } \\
\text { cryptorchidism (yes/no) }\end{array}$ & No & & LH (IU/L) & 2.4 \\
\hline & & & Testicular size $(\mathrm{mL})$ & $3 / 3$ & & FSH $(\mathrm{IU} / \mathrm{L})$ & 4.6 \\
\hline & & & $\mathrm{LH}(\mathrm{IU} / \mathrm{L})$ & 0.86 & & Testosterone (ng/dL) & 71 \\
\hline & & & FSH (IU/L) & 0.86 & & & \\
\hline & & & $\mathrm{LH} 60 \mathrm{~min}(\mathrm{IU} / \mathrm{L})$ & 1.30 & & & \\
\hline & & & Testosterone (ng/dL) & 67.00 & & & \\
\hline \multirow{8}{*}{ Patient 4} & \multirow{8}{*}{$\begin{array}{l}\text { Kallmann } \\
\text { syn }\end{array}$} & \multirow{8}{*}{$\begin{array}{l}\text { Mutation- } \\
\text { negative }\end{array}$} & $\begin{array}{c}\text { Age for starting spermatogenic } \\
\text { therapy (year) }\end{array}$ & 19 & \multirow{8}{*}{ GnRH pulsatile } & $\begin{array}{l}\text { Follow-up duration } \\
\text { (months) }\end{array}$ & 36 \\
\hline & & & BMI $\left(\mathrm{kg} / \mathrm{m}^{2}\right)$ & 24.6 & & Testicular size $(\mathrm{mL})$ & $10 / 8$ \\
\hline & & & $\begin{array}{l}\text { History of cryptorchidism or } \\
\text { cryptorchidism (yes/no) }\end{array}$ & Yes & & LH (IU/L) & 7 \\
\hline & & & Testicular size $(\mathrm{mL})$ & $0 / 0$ & & FSH (IU/L) & 3.5 \\
\hline & & & $\mathrm{LH}(\mathrm{IU} / \mathrm{L})$ & 0.3 & & Testosterone (ng/dL) & 32.8 \\
\hline & & & FSH (IU/L) & 0.43 & & & \\
\hline & & & LH $60 \mathrm{~min}(\mathrm{IU} / \mathrm{L})$ & 1.06 & & & \\
\hline & & & Testosterone (ng/dL) & 30.00 & & & \\
\hline \multirow{8}{*}{ Patient 5} & \multirow{8}{*}{$\begin{array}{l}\text { Kallmann } \\
\text { syn }\end{array}$} & \multirow{8}{*}{$\begin{array}{l}\text { Mutation- } \\
\text { negative }\end{array}$} & $\begin{array}{c}\text { Age for starting spermatogenic } \\
\text { therapy (year) }\end{array}$ & 25 & \multirow{8}{*}{ Gonadotropin } & $\begin{array}{l}\text { Follow-up duration } \\
\text { (months) }\end{array}$ & 30 \\
\hline & & & BMI $\left(\mathrm{kg} / \mathrm{m}^{2}\right)$ & 24.2 & & Testicular size $(\mathrm{mL})$ & $3 / 3$ \\
\hline & & & $\begin{array}{l}\text { History of cryptorchidism or } \\
\text { cryptorchidism (yes/no) }\end{array}$ & No & & $\mathrm{LH}(\mathrm{IU} / \mathrm{L})$ & 0.20 \\
\hline & & & Testicular size $(\mathrm{mL})$ & $1 / 1$ & & FSH (IU/L) & 0.18 \\
\hline & & & LH (IU/L) & 0.35 & & Testosterone (ng/dL) & 110 \\
\hline & & & FSH (IU/L) & 0.35 & & & \\
\hline & & & LH 60 min (IU/L) & 0.57 & & & \\
\hline & & & Testosterone (ng/dL) & 20.5 & & & \\
\hline \multirow{8}{*}{ Patient 6} & \multirow{8}{*}{$\mathrm{nCHH}$} & \multirow{8}{*}{$\begin{array}{l}\text { Mutation- } \\
\text { negative }\end{array}$} & $\begin{array}{c}\text { Age for starting spermatogenic } \\
\text { therapy (year) }\end{array}$ & 24 & \multirow{8}{*}{ GnRH pulsatile } & $\begin{array}{l}\text { Follow-up duration } \\
\text { (months) }\end{array}$ & 26 \\
\hline & & & BMI $\left(\mathrm{kg} / \mathrm{m}^{2}\right)$ & 24.1 & & Testicular size $(\mathrm{mL})$ & $\begin{array}{c}12 / \\
12\end{array}$ \\
\hline & & & $\begin{array}{l}\text { History of cryptorchidism or } \\
\text { cryptorchidism (yes/no) }\end{array}$ & No & & LH (IU/L) & 9.04 \\
\hline & & & Testicular size $(\mathrm{mL})$ & $\begin{array}{c}2.5 / \\
2.5\end{array}$ & & FSH (IU/L) & 4.99 \\
\hline & & & LH (IU/L) & 0.2 & & Testosterone (ng/dL) & 148 \\
\hline & & & FSH (IU/L) & 0.2 & & & \\
\hline & & & LH 60 min (IU/L) & 1.04 & & & \\
\hline & & & Testosterone (ng/dL) & 34 & & & \\
\hline
\end{tabular}

Testicular volume, FSH, LH, and testosterone levels were all obtained by the average of the last two measurements.

the $\mathrm{MN}$ group (7.19 million/mL vs. 18.80 million $/ \mathrm{mL}$ ), although the sperm mobility was similar for the two groups.

In our study, mutated FGFR1 was speculated as pathogenic and disease-causing, based on the following evidence: (1) in this study, patients in the FM group were single-gene mutant; (2) according to the criteria of the ACMG guidelines [12], half of the mutants were pathogenic or likely pathogenic (7/14); (3) four patients were further analyzed and had de novo mutations. Our previous study showed that most of the FGFR1 gene mutations (11/12) were de novo
(Supplementary Table 2), suggesting that the mutated FGFR1 is most likely pathogenic in this group.

Patients with FGFR1 mutations have a more severe impairment of the reproductive phenotype, mainly manifested by a high incidence of cryptorchidism and smaller testis volume during spermatogenesis treatment. Our study found that the incidence of cryptorchidism in patients with FGFR1 gene mutations was $50 \%$, which is consistent with previous studies [5]. The prevalence of cryptorchidism in the $\mathrm{CHH}$ population is $10-20 \%[13,17]$. The incidence of cryptorchidism in patients with FGFR1, ANOS1, and CHD7 
mutations is $50-60 \%[5,18], 38.1-66 \%[19,0]$, and $50-70 \%$ [21], respectively. As FGFR1 is expressed in Leydig cells, Sertoli cells, and spermatogonia, its function is important for testicular development and spermatogenesis [22-26]. Therefore, the inactivating mutation may impair spermatogenesis through a testicular pathway. Currently, there has not been a study focusing on sperm production in patients with FGFR1 gene mutations.

The presence of cryptorchidism is not only a reflection of severe reproductive axis damage but also a harmful predictive factor of spermatogenesis [27, 28]. It has been shown that the success rate of spermatogenesis in $\mathrm{CHH}$ with cryptorchidism is lower than patients without cryptorchidism $(50 \%$ vs. $67 \%, p=0.032)$. In these patients, a longer time was needed to achieve the first appearance of sperm [29]. Several detrimental conditions may impair the progress of spermatogenesis. First, undescended testis was associated with a higher surrounding temperature and the optimal temperature for spermatogenesis $\left(33^{\circ} \mathrm{C}\right)$ cannot be maintained [30]. Higher ambient temperature would impair gonocyte maturation [31]. Secondly, additional oxidative stress and inflammation in the undescended testis would impair sperm quality [32]. The higher incidence of cryptorchidism may be the reason for the longer time of spermatogenesis in the FM group.

In our study, after two years of sperm-inducing treatment, the success rate of the FM and MN groups was $75.89 \%$ and $82.14 \%$, respectively. According to the meta-analysis results from several studies, the overall success rate is $74-90 \%$ in patients receiving pulsatile GnRH therapy [33] and 69.2-94.4\% in patients receiving gonadotropin therapy $[34,35]$. No clear genetic diagnosis was made in these $\mathrm{CHH}$ patients. Although the success rate of spermatogenesis in FGFR1 and MN groups was similar, the median time for first sperm appearance was longer in the FM group.

There is no study on the evaluation of spermatogenic effects on patients with different genotypes. The possible reasons are as follows: (1) it is difficult to make a gene diagnosis on patients with $\mathrm{CHH}$, as many patients do not have gene variations, while some have multiple gene mutations [36]. (2) Patients with the same mutation have different clinical phenotypes. For example, for the same FGFR1 mutation, some presented $\mathrm{CHH}$, while others showed delayed puberty $[1,37]$. Patients with the same PROKR2 mutations also have variable reproductive conditions [5]. These variable conditions make it difficult to accurately evaluate the effects of sperm promoting therapy. (3) The number of patients with the same gene mutation and spermatogenic treatment is too small to be statistically analyzed.

FGFR1 may impair spermatogenesis at the hypothalamus, pituitary, and testis levels. It was found that $25.6 \%$ (23/90) of $\mathrm{CHH}$ patients had a poor testicular response to gonadotropins and $11.1 \%(10 / 90)$ had a poor response to pulsatile GnRH therapy, indicating defects in the pituitary gland and testicular levels [38]. FGFR1 gene mutations may result in a weaker response of Leydig cells and spermatogonia to gonadotropins. Therefore, patients need longer treatment time to promote testicular volume and spermatogenesis.
In this study, two patients with FGFR1 gene mutations and cryptorchidism history had a failure of spermatogenesis after two years of treatment. In patient 1 (Table 4), the LH and FSH level increased during pulsatile GnRH therapy, while the testosterone level did not significantly increase. In patient 2, the testosterone level did not significantly increase after gonadotropin therapy. Both patients indicated impaired Leydig cell function. In the MN group, four patients had a failure of spermatogenesis after two years of treatment. All of the patients did not reach normal levels of testosterone, suggesting that patients in the $\mathrm{MN}$ group may also have damaged Leydig cell function.

The classical pathogenesis of $\mathrm{CHH}$ is associated with defective GnRH neuron differentiation and migration. FGFR1 gene mutations not only cause defective GnRH neurons in the hypothalamus but also lead to the damage of pituitary gonadotropin cells. Some mutations may result in anterior pituitary hypoplasia and a deficiency of multiple pituitary hormones [39]. The multilevel damage in the gonadal axis may also explain why the FM group requires longer time for sperm production.

The shortcomings of this study are as follows: (1) the sample size is too small to accurately reflect the entire possible spermatogenic outcomes in the FGFR1 gene mutation population. However, as a rare disease, the description of 14 cases provides a valuable opportunity to observe the change of reproductive axis function. (2) In this study, the $\mathrm{MN}$ group was defined by having no known $\mathrm{CHH}$ related genes. Other gene mutations causing $\mathrm{CHH}$ could not be excluded. (3) Pulsatile GnRH and gonadotropin therapies have different mechanisms to induce sperm. Due to the small sample size, the disparity between the two therapeutic methods could not be further analyzed. (4) The mutation pathogenicity was determined based on the ACMG guidelines, not by in vitro verification.

In conclusion, gonadal axis defects were more severe in $\mathrm{CHH}$ patients with FGFR1 mutations, presenting a higher incidence of cryptorchidism, smaller testicular size, and longer time required for sperm production. However, the rate of successful spermatogenesis in different sperm concentration thresholds was similar between patients with FGFR1 mutations and nonmutation patients, providing valuable evidence and confidence for sperm promoting therapy for these patients.

\section{Data Availability}

The data used to support the findings of this study are included within the article.

\section{Conflicts of Interest}

The authors declare that they have no conflicts of interest.

\section{Authors' Contributions}

Shuying Li and Yaling Zhao contributed equally to this paper. 


\section{Acknowledgments}

This work was supported by the National Key Research and Development Program of China (2016YFC0905102 and 2016YFA0101003); CAMS Innovation Fund for Medical Sciences (CIFMS) (2016-I2M-1-002 and 2017-I2M-3-007); the Project of National Natural Science Foundation of China (81771576 and 81971375); Beijing Municipal Natural Science Foundation (7202151).

\section{Supplementary Materials}

Supplementary material 1 includes two supplementary tables: supplementary table 1 shows $\mathrm{CHH}$-related genes included in the panel; supplementary table 2 shows the source analysis of FGFR1, PROKR2, ANOS1 gene mutations. Supplementary material 2 shows gene sequencing flow. (Supplementary Materials)

\section{References}

[1] A. K. Topaloglu and L. D. Kotan, "Genetics of hypogonadotropic hypogonadism," Endocrine Development, vol. 29, p. 36, 2016.

[2] L. Maione, A. A. Dwyer, B. Francou et al., "Genetics in endocrinology: genetic counseling for congenital hypogonadotropic hypogonadism and kallmann syndrome: new challenges in the era of oligogenism and next-generation sequencing," European Journal of Endocrinology, vol. 178, p. 17, 2018.

[3] L. G. L. Amato, L. R. Montenegro, A. M. Lerario et al., "New genetic findings in a large cohort of congenital hypogonadotropic hypogonadism," European Journal of Endocrinology, vol. 181, no. 2, p. 103, 2019.

[4] M. I. Stamou and N. A. Georgopoulos, "Kallmann syndrome: phenotype and genotype of hypogonadotropic hypogonadism," Metabolism, vol. 86, p. 124, 2018.

[5] J. Mao, Influence of Gene Mutations on Hypothalamus Pituitary Gonad Axis Function and Gonadotropin Induced Spermatogenesis in Male Patients with Idiopathic Hypogonadotropic Hypogonadism, Doctor. Peking: Peking Union Medical College, Beijing, China, 2012.

[6] V. Koika, P. Varnavas, H. Valavani et al., "Comparative functional analysis of two fibroblast growth factor receptor 1 (FGFR1) mutations affecting the same residue (R254W and R254Q) in isolated hypogonadotropic hypogonadism (IHH)," Gene, vol. 516, no. 1, p. 146, 2013.

[7] A. Kurowski, A. Molotkov, and P. Soriano, "FGFR1 regulates trophectoderm development and facilitates blastocyst implantation," Developmental Biology, vol. 446, no. 1, p. 94, 2019.

[8] C. Gonçalves, M. Bastos, D. Pignatelli et al., "Novel FGFR1 mutations in Kallmann syndrome and normosmic idiopathic hypogonadotropic hypogonadism: evidence for the involvement of an alternatively spliced isoform," Fertility and Sterility, vol. 104, no. 5, p. 1261, 2015.

[9] M. Katoh, "FGFR inhibitors: effects on cancer cells, tumor microenvironment and whole-body homeostasis (Review)," International Journal of Molecular Medicine, vol. 38, no. 1, p. 3, 2016.

[10] M. E. Woodbury and T. Ikezu, "Fibroblast growth factor-2 signaling in neurogenesis and neurodegeneration," Journal of Neuroimmune Pharmacology, vol. 9, no. 2, p. 92, 2014.
[11] N. Simonis, I. Migeotte, N. Lambert et al., "FGFR1mutations cause Hartsfield syndrome, the unique association of holoprosencephaly and ectrodactyly," Journal of Medical Genetics, vol. 50, no. 9, p. 585, 2013.

[12] L. G. Biesecker and S. M. Harrison, "The ACMG/AMP reputable source criteria for the interpretation of sequence variants," Genetics in Medicine, vol. 20, no. 12, p. 1687, 2018.

[13] B. Bhagavath, R. H. Podolsky, M. Ozata et al., "Clinical and molecular characterization of a large sample of patients with hypogonadotropic hypogonadism," Fertility and Sterility, vol. 85, no. 3, p. 706, 2006.

[14] A. K. Topaloğlu, "Update on the genetics of idiopathic hypogonadotropic hypogonadism," Journal of Clinical Research in Pediatric Endocrinology, vol. 113, 2018.

[15] Y. J. Kim, D. P. Osborn, J. Y. Lee et al., "WDR11-mediated Hedgehog signalling defects underlie a new ciliopathy related to Kallmann syndrome," EMBO Reports, vol. 19, no. 2, p. 269, 2018.

[16] R. K. Semple and A. K. Topaloglu, "The recent genetics of hypogonadotrophic hypogonadism - novel insights and new questions," Clinical Endocrinology, vol. 72, no. 4, p. 427, 2010.

[17] P. Y. Liu, H. W. G. Baker, V. Jayadev, M. Zacharin, A. J. Conway, and D. J. Handelsman, "Induction of spermatogenesis and fertility during gonadotropin treatment of gonadotropin-deficient infertile men: predictors of fertility outcome," The Journal of Clinical Endocrinology \& Metabolism, vol. 94, no. 3, p. 801, 2009.

[18] N. Pitteloud, A. Meysing, R. Quinton et al., "Mutations in fibroblast growth factor receptor 1 cause Kallmann syndrome with a wide spectrum of reproductive phenotypes," Molecular and Cellular Endocrinology, vol. 254, p. 60, 2006.

[19] M. Nie, H. Xu, R. Chen et al., "Analysis of genetic and clinical characteristics of a Chinese Kallmann syndrome cohort with ANOS1 mutations," European Journal of Endocrinology, vol. 177, no. 4, p. 389, 2017.

[20] S. Salenave, P. Chanson, H. Bry et al., "Kallmann's syndrome: a comparison of the reproductive phenotypes in men carrying KAL1 and FGFR1/KAL2 mutations," The Journal of Clinical Endocrinology \& Metabolism, vol. 93, no. 3, p. 758, 2008.

[21] P. Hsu, A. Ma, M. Wilson et al., "Charge syndrome: a review," Journal of Paediatrics and Child Health, vol. 50, no. 7, p. 504, 2014.

[22] Y. Hu and P.-M. Bouloux, "Novel insights in FGFR1 regulation: lessons from Kallmann syndrome," Trends in Endocrinology \& Metabolism, vol. 21, no. 6, p. 385, 2010.

[23] N. O. Hadziselimovic, C. de Geyter, P. Demougin, E. J. Oakeley, and F. Hadziselimovic, "Decreased expression of FGFR1, SOS1, RAF1 genes in cryptorchidism," Urologia Internationalis, vol. 84, no. 3, p. 353, 2010.

[24] B. Le Magueresse-Battistoni, J. Wolff, A. M. Morera, and M. Benahmed, "Fibroblast growth factor receptor type 1 expression during rat testicular development and its regulation in cultured Sertoli cells," Endocrinology, vol. 135, no. 6, p. 2404, 1994.

[25] L. Chen, X. Li, Y. Wang et al., "Fibroblast growth factor 1 promotes rat stem Leydig cell development," Front Endocrinol (Lausanne), vol. 10, p. 118, 2019.

[26] B. Cancilla and G. P. Risbridger, "Differential localization of fibroblast growth factor receptor-i, $-2,-3$, and -4 in fetal, immature, and adult rat Testes1," Biology of Reproduction, vol. 58 , no. 5, p. $1138,1998$.

[27] D. M. Finkel, J. L. Phillips, and P. J. Snyder, "Stimulation of spermatogenesis by gonadotropins in men with 
hypogonadotropic hypogonadism," New England Journal of Medicine, vol. 313, no. 11, p. 651, 1985.

[28] J. M. W. Kirk, M. O. Savage, D. B. Grant, P.-M. G. Bouloux, and G. M. Besser, "Gonadal function and response to human chorionic and menopausal gonadotrophin therapy in male patients with idiopathic hypogonadotrophic hypogonadism," Clinical Endocrinology, vol. 41, no. 1, p. 57, 1994.

[29] Z. Liu, J. Mao, H. Xu et al., "Gonadotropin-induced spermatogenesis in $\mathrm{CHH}$ patients with cryptorchidism," International Journal of Endocrinology, vol. 2019, Article ID 6743489, , 2019.

[30] G. Cobellis, C. Noviello, F. Nino et al., "Spermatogenesis and cryptorchidism," Front Endocrinol (Lausanne), vol. 5, p. 63, 2014.

[31] R. Ivell and S. Hartung, "The molecular basis of cryptorchidism," Molecular Human Reproduction, vol. 9, no. 4, p. 175, 2003.

[32] M. Imamoglu, S. S. Bulbul, N. Kaklikkaya, and H. Sarihan, "Oxidative, inflammatory and immunologic status in children with undescended testes," Pediatrics International, vol. 54, p. 816, 2012.

[33] L. Zhang, K. Cai, Y. Wang et al., "The pulsatile gonadorelin pump induces earlier spermatogenesis than cyclical gonadotropin therapy in congenital hypogonadotropic hypogonadism men," American Journal of Men's Health, vol. 13, Article ID 1817096168, 2019.

[34] D. W. Warne, G. Decosterd, H. Okada, Y. Yano, N. Koide, and C. M. Howles, "A combined analysis of data to identify predictive factors for spermatogenesis in men with hypogonadotropic hypogonadism treated with recombinant human follicle-stimulating hormone and human chorionic gonadotropin," Fertility and Sterility, vol. 92, no. 2, p. 594, 2009.

[35] E. Nieschlag, P. G. Bouloux, B. J. Stegmann, R. R. Shankar, Y. Guan, and A. Tzontcheva, "McCrary Sisk C., Behre H.M.: an open-label clinical trial to investigate the efficacy and safety of corifollitropin alfa combined with hCG in adult men with hypogonadotropic hypogonadism," Reproductive Biology and Endocrinology, vol. 15, 2017.

[36] A. L. Mitchell, A. Dwyer, N. Pitteloud, and R. Quinton, "Genetic basis and variable phenotypic expression of Kallmann syndrome: towards a unifying theory," Trends in Endocrinology and Metabolism: TEM, vol. 22, no. 7, p. 249, 2011.

[37] M. Men, J. Wu, Y. Zhao et al., "Genotypic and phenotypic spectra of FGFR1, FGF8, and FGF17 mutations in a Chinese cohort with idiopathic hypogonadotropic hypogonadism," Fertility and Sterility, vol. 113, no. 1, p. 158, 2020.

[38] G. P. Sykiotis, X.-H. Hoang, M. Avbelj et al., "Congenital idiopathic hypogonadotropic hypogonadism: evidence of defects in the hypothalamus, pituitary, and testes," The Journal of Clinical Endocrinology \& Metabolism, vol. 95, no. 6, p. 3019, 2010.

[39] P.-S. Tsai, S. M. Moenter, H. R. Postigo et al., "Targeted expression of a dominant-negative fibroblast growth factor (FGF) receptor in gonadotropin-releasing hormone $(\mathrm{GnRH})$ neurons reduces FGF responsiveness and the size of GnRH neuronal population," Molecular Endocrinology, vol. 19, no. 1, p. 225, 2005. 